\title{
Afferent Deprivation Elicits a Transcriptional Response Associated with Neuronal Survival after a Critical Period in the Mouse Cochlear Nucleus
}

\author{
Julie A. Harris, ${ }^{1,2}$ Fukuichiro Iguchi, ${ }^{1}$ Armin H. Seidl, ${ }^{1}$ Diana I. Lurie, ${ }^{3}$ and Edwin W Rubel ${ }^{1,2}$ \\ ${ }^{1}$ Department of Otolaryngology, Head and Neck Surgery, Virginia Merrill Bloedel Hearing Research Center, and ${ }^{2}$ Graduate Program in Neurobiology and \\ Behavior, University of Washington, Seattle, Washington 98195, and ${ }^{3}$ Department of Biomedical and Pharmaceutical Sciences, University of Montana, \\ Missoula, Montana 59812
}

\begin{abstract}
The mechanisms underlying enhanced plasticity of synaptic connections and susceptibilities to manipulations of afferent activity in developing sensory systems are not well understood. One example is the rapid and dramatic neuron death that occurs after removal of afferent input to the cochlear nucleus $(\mathrm{CN})$ of young mammals and birds. The molecular basis of this critical period of neuronal vulnerability and the transition to survival independent of afferent input remains to be defined. Here we used microarray analyses, real-time reverse transcription PCR, and immunohistochemistry of the mouse $\mathrm{CN}$ to show that deafferentation results in strikingly different sets of regulated genes in vulnerable [postnatal day (P) 7] and invulnerable (P21) CN. An unexpectedly large set of immune-related genes was induced by afferent deprivation after the critical period, which corresponded with glial proliferation over the same time frame. Apoptotic gene expression was not highly regulated in the vulnerable $\mathrm{CN}$ after afferent deprivation but, surprisingly, did increase after deafferentation at P21, when all neurons ultimately survive. Pharmacological activity blockade in the eighth nerve mimicked afferent deprivation for only a subset of the afferent deprivation regulated genes, indicating the presence of an additional factor not dependent on action potential-mediated signaling that is also responsible for transcriptional changes. Overall, our results suggest that the cell death machinery during this critical period is mainly constitutive, whereas after the critical period neuronal survival could be actively promoted by both constitutive and induced gene expression.
\end{abstract}

Key words: microarray; critical period; cochlear nucleus; activity-dependent; apoptosis; deafferentation; stability

\begin{abstract}
Introduction
Afferent input is required for the normal development of synaptic connectivity and neuron number in most sensory systems, including the auditory system (Levi-Montalcini, 1949; Wiesel and Hubel, 1963; Van der Loos and Woolsey, 1973; Born and Rubel, 1985; Brunjes, 1994). Eliminating afferent input to the cochlear nucleus of birds and mammals by cochlear removal results in dramatic neuron death in the immature cochlear nucleus (CN). In mammals this effect is confined to a short postnatal critical period (Hashisaki and Rubel, 1989; Moore, 1990; Tierney et al., 1997; Mostafapour et al., 2000). Specifically in mice, CN neurons are highly vulnerable to cochlear removal at ages up to
\end{abstract}

Received June 12, 2008; revised Aug. 11, 2008; accepted Sept. 23, 2008.

This work was supported by National Institute on Deafness and Other Communication Disorders Grants DC03829, DC04661, DC05361, and DC07001. We thank Rachel Nehmer, Abigail Wark, and Dr. Maike Hartlage-Rubsamen for assistance in tissue and data collection and Diane Brooks for expert technical assistance in PCNA labeling and analysis. We are also extremely grateful to Dr. Rob Hall at the Center for Array Technologies at the University of Washington for his help in completing the TTX arrays.

Correspondence should be addressed to Dr. Edwin W Rubel, Virginia Merrill Bloedel Hearing Research Center, Box 357923, CHDD Bldg, Rm CD176, University of Washington, Seattle, WA 98195-7923. E-mail: rubel@u.washington.edu.

J. A. Harris's present address: Gladstone Institute of Neurological Disease, University of California, San Francisco, CA 94158.

D0I:10.1523/JNEUROSCI.2697-08.2008

Copyright $\odot 2008$ Society for Neuroscience $\quad$ 0270-6474/08/2810990-13\$15.00/0 postnatal day (P) 11, when 25-66\% neuron loss occurs, but not at P14 or older (Mostafapour et al., 2000). Importantly, the end of this critical period coincides with the onset of hearing in all mammalian species studied to date. The molecular basis of this rapid developmental switch in neuronal vulnerability is still largely unknown.

Susceptible CN neurons die by an apoptotic-like process after cochlear removal (for review see Harris and Rubel, 2006). Caspase 3 cleavage increases in P7 mouse CN neurons 12-24 h after cochlear removal, followed by a peak in TUNEL at $48 \mathrm{~h}$, preceding maximal neuron loss at $96 \mathrm{~h}$ (Mostafapour et al., 2000; Mostafapour et al., 2002). A pathway involving NFAT-dependent transcription has also been recently implicated in apoptotic neuronal death in the deafferented immature mouse CN (Luoma and Zirpel, 2008). These results support the hypothesis that apoptotic gene expression could be involved in defining this critical period window. Indeed, genetic manipulation of bcl-2 alters the agedependent response to deafferentation in the $\mathrm{CN}$ (Mostafapour et al., 2000; Mostafapour et al., 2002), and constitutive differences in apoptotic gene expression in the $\mathrm{CN}$ during compared with after this critical period strongly correlate with neuronal fate after cochlear removal (Harris et al., 2005).

Identifying the mechanisms of cell death after deafferentation during this critical period has been a major focal point. However, 
the possibility that neuron survival after cochlear removal is also an active process has not been explored. Therefore we used microarrays to assess the transcriptional response in the $\mathrm{CN}$ during the first $48 \mathrm{~h}$ after cochlear removal at P7 and P21. Surprisingly, we found a similar number of genes significantly regulated by deafferentation at both ages, although only $10 \%$ were the same. In addition, few apoptotic genes were upregulated by deafferentation at P7, whereas a larger apoptotic gene response was detected at P21. Most striking was the large immune response and corresponding glial proliferation after cochlear removal at P21, suggesting a possible neuroprotective role of glia in actively defining this critical period window.

Finally, we analyzed whether these transcriptional changes were caused by loss of electrical activity in the eighth nerve. Pharmacological activity blockade of the auditory nerve for 6 or $24 \mathrm{~h}$ resulted in similar expression changes for only a subset of genes. Thus, an additional factor not dependent on action potentialmediated signaling must also regulate transcriptional responses to deafferentation in the $\mathrm{CN}$.

\section{Materials and Methods}

Animals. Male and female C57BL/6J mice were used at postnatal days 7 (P7) and 21. Pups were considered $0 \mathrm{~d}$ (P0) on the day of birth. The University of Washington Institutional Animal Care and Use Committee approved all procedures.

Cochlear removals. Mice were anesthetized with inhaled isoflurane delivered from a gas vaporizer anesthesia machine. Hair inferior to the pinna was removed when present and the area scrubbed with Betadine. Lidocaine $(1 \%)$ was injected below the skin in the area of the first incision. Cuts were made below the pinna to expose and open the ear canal. The tympanic membrane was punctured, ossicles removed, and the basal turn of the cochlea identified. A hole was made in the bone and the contents of the cochlea aspirated through a fine glass pipette. The hole was packed with sterile Gelfoam and the skin incision closed with cyanoacrylic glue. Mice were kept warm until fully awake and returned to their littermates and/or dams within 1-2 h.

Tetrodotoxin implants for $6 \mathrm{~h}$ treatment. Tetrodotoxin (TTX) (\#T-550, Alomone labs) was embedded in polyvinyl alcohol (PVA, DuPont) for short-term slow release. PVA $(16 \% \mathrm{w} / \mathrm{v})$ was dissolved in distilled water warmed to $85^{\circ} \mathrm{C}$ for $6 \mathrm{~h} .7 .5$ (for P7) or 75 (for P21) $\mu$ l of $3 \mathrm{~mm}$ TTX in citrate buffer was added to $250 \mu \mathrm{l}$ of the $16 \%$ PVA solution. The mixture was poured into wells of a 24-well plate and subjected to two freeze-thaw cycles $\left(16 \mathrm{~h}\right.$ at $-20^{\circ} \mathrm{C}, 8 \mathrm{~h}$ at room temperature). Plugs of the TTX/PVA mixture were cut to fit into the round window just before use. Unilateral surgery proceeded as described above for cochlear removals except that a small hole was made in the posterior edge of the tympanic membrane and the ear canal was widened slightly by chipping away some of the auditory bulla to expose the round window niche. The TTX implant was placed through the hole near the round window without disturbing the ossicles. Pups ( $n=3$ /age group) were allowed to survive for $6 \mathrm{~h}$, then $\mathrm{CN}$ tissue was isolated from the ipsilateral and unmanipulated contralateral sides for real-time reverse transcription (RT) PCR analyses.

TTX implants for $24 \mathrm{~h}$ treatment. Osmotic pumps (1003D, $1 \mu \mathrm{l} / \mathrm{h}$; Durect Corporation, Cupertino, CA) were filled with $100 \mu \mathrm{M}$ TTX and placed in a $38^{\circ} \mathrm{C} 0.9 \%$ saline bath for $12 \mathrm{~h}$, which allowed the pump to be operational immediately on implantation. A fine cannula was made for cochlear infusion of TTX using a $7 \mathrm{~mm}$ piece of polyethylene tubing (PE-90, $1.27 \mathrm{~mm}$ OD, $0.86 \mathrm{~mm}$ ID) inserted in the end of a second $7 \mathrm{~mm}$ piece of polyethylene tubing (PE-50, $0.97 \mathrm{~mm}$ OD, $0.58 \mathrm{~mm}$ ID). These tubes were then connected to a $4 \mathrm{~cm}$ piece of polyethylene tubing ( $\mathrm{PE}-10$, $0.61 \mathrm{~mm}$ OD, $0.28 \mathrm{~mm}$ ID). To implant the pumps and insert the cannula into the cochlea, P21 mice were anesthetized with ketamine $(100 \mathrm{mg} / \mathrm{kg})$ and xylazine $(10 \mathrm{mg} / \mathrm{kg})$. A retro-auricular incision was made and a small hole $(0.6 \mathrm{~mm})$ was made in the bulla to expose the round window niche and stapedial artery, which was cauterized. A subcutaneous pocket was formed between the scapulae to accommodate the pump. The tip of the prefilled cannula was inserted into the hole on the bulla until the tip was seated in the round window niche. The cannula was glued to the bulla, and TTX was infused at $1 \mu \mathrm{l} / \mathrm{h}$. Mice were killed $24 \mathrm{~h}$ later and $\mathrm{CN}$ tissues were collected from the ipsilateral and unmanipulated contralateral side for RNA isolation and microarray hybridizations.

Auditory brainstem response recordings. Hearing thresholds before and after TTX exposure were evaluated with auditory brainstem responses (ABRs) recorded in response to clicks. Anesthetized mice were placed in a sound-attenuating chamber. Body temperature was maintained at $\sim 37^{\circ} \mathrm{C}$ by an isothermal heating pad (Braintree Scientific). Evoked responses were recorded via subdermal needle electrodes placed midline above the frontal bone (positive) and behind the left pinna, with a ground electrode in the left thigh. The system was calibrated on each day of use (\#2530; Larson-Davis) with the microphone tip placed at the location of the mouse head. Click levels and hearing thresholds were determined in $\mathrm{dB}$ peak equivalent sound pressure level ( $\mathrm{dB}$ per SPL) referenced to an $8 \mathrm{kHz}$ tone. Click stimuli of alternating polarity were repeated at $75 \mathrm{~ms}$ intervals in $10 \mathrm{~dB}$ increments starting at $92 \mathrm{~dB}$ and decreasing to $32 \mathrm{~dB}$. ABRs were recorded over $40 \mathrm{~ms}$ and averaged at each intensity level for 1024 presentations. Potentials were amplified $(1000 \times)$, filtered $(0.3-3 \mathrm{kHz})$ by a preamplifier (P55; Grass-Telefactor) and digitized. Threshold was determined visually as the lowest SPL (in $5 \mathrm{~dB}$ increments) in which a recognizable waveform was present and repeatable.

CN tissue dissection and RNA isolation. Mice were decapitated 6, 12, 24, and $48 \mathrm{~h}$ after unilateral cochlear removal $(n=24-36 /$ time point for each age). Using a dissecting microscope, the cochlea was gently pulled away from the brainstem and the eighth nerve cut. After removal of the overlying cerebellar flocculus, the CN was dissected out bilaterally. Separate pools of $\mathrm{CN}$ tissue ipsilateral and contralateral to the lesion from 12 mice were used for each replicate array. Tissue was immediately frozen in liquid $\mathrm{N}_{2}$ and stored at $-80^{\circ} \mathrm{C}$. Total RNA was isolated using the Qiagen Lipid RNeasy Mini kit. RNA concentration and integrity were assessed using an Agilent 2100 Bioanalyzer. Approximately $0.75 \mu \mathrm{g}$ of total RNA was obtained per CN.

Microarrays. Affymetrix Mouse Expression Set 430A GeneChips were used to compare relative levels of mRNA expression between the ipsilateral and contralateral $\mathrm{CN}$ at $6 \mathrm{~h}(n=2$ arrays $), 12 \mathrm{~h}(n=3), 24 \mathrm{~h}(n=3)$, and $48 \mathrm{~h}(n=3)$ after surgery. Mouse Expression Set 430A 2.0 GeneChips were used for the comparison between $\mathrm{CN}$ ipsilateral and contralateral to TTX-treated ears ( $n=3$ arrays).

Preparation of labeled cRNA, hybridization, array scanning, and image analysis. The Center for Array Technologies at the University of Washington performed the following procedures. Biotinylated labeled target cRNA was prepared and hybridized to the Mouse 430A GeneChip with minor modifications from the Affymetrix recommended procedures. Briefly, $6.4 \mu \mathrm{g}$ of total RNA was reverse transcribed into double-stranded cDNA using a T7-(dT)24 primer in the presence of $10 \mathrm{~mm}$ dNTP mix and poly-A spike in positive control RNAs during first strand synthesis (Invitrogen). Double-stranded cDNA was used as a template for synthesis of biotin-labeled cRNA (Enzo Diagnostics). Labeled cRNA was cleaned up to remove unincorporated NTPs and the concentration was determined spectrophotometrically. According to Affymetrix protocols, $15 \mu \mathrm{g}$ of cRNA was then fragmented and transcript sizes were analyzed on the Bioanalyzer to be between 50 and 200 bp. Spike-in eukaryotic hybridization controls were added to the cRNA samples, and hybridization to the GeneChips was performed for $16 \mathrm{~h}$ at $45^{\circ} \mathrm{C}$. Using the Affymetrix GeneChip System, arrays were then washed and stained with streptavidinphycoerythrin (Molecular Probes) before being scanned using a GeneChip Scanner. The quality of hybridizations and overall chip performance was determined by visual inspection of the raw scanned data for artifacts, scratches, or bubbles. The Affymetrix Gene Chip Operating System (GCOS) report file $\left({ }^{*}\right.$.RPT) was used to determine whether the following statistics were within acceptable limits: $3^{\prime} / 5^{\prime}$ GAPDH and $\beta$-actin ratios did not exceed 1.5, chip background and noise were below cutoff limits, and hybridization spike-in controls were present and in increasing intensities. Background and noise were similar across all arrays used for comparisons. Using the raw image file in GCOS (.DAT), cell intensities were calculated and the resulting files (.CEL) containing intensity information for all probes on the arrays were up- 
loaded into the software program Genesifter. net (VizX Laboratories, Seattle, WA) for further analyses.

Array data analysis. Normalization of the raw microarray data and determination of differential expression was done with Genesifter software. GC-robust multiarray average (RMA) normalization was performed on the Affymetrix GeneChips (Irizarry et al., 2003). At each time point, fold changes were calculated for the ipsilateral vs contralateral samples. Lists of genes showing differential expression after cochlear removal were generated using two filtering criteria: a $p$-value cutoff of $\leq 0.05$ after a Student's $t$ test and a fold change threshold of $\geq 1.5$. False discovery rate (FDR) analysis using the Benjamini and Hochberg correction was applied to this prefiltered list of genes. All genes were accepted at a FDR of 5\%. A comprehensive list was compiled that included all of the genes significantly altered in expression by cochlear removal in at least one of the time points after surgery. The entire deafferentation and TTX microarray datasets are available in the Gene Expression Omnibus public repository (http://www.ncbi.nlm.nih.gov, series number GSE5394 and GSE11726).

Real-time RT PCR. Real-time RT PCR was performed on a Bio-Rad iCycler System using SYBR Green detection (Bio-Rad). cDNA template was made from $1 \mu \mathrm{g}$ of total RNA using the Bio-Rad iScript cDNA Synthesis kit. The PCRs contained $12.5 \mu \mathrm{l}$ of SYBR green Supermix, $5 \mu \mathrm{l}$ of cDNA template, $0.375 \mu$ l each of the forward and reverse primers $(800$ $\mathrm{nm}$ ), and $6.75 \mu \mathrm{l}$ of water. The conditions were $95^{\circ} \mathrm{C}$ for $3 \mathrm{~min}$ followed by 45 cycles of denaturing at $95^{\circ} \mathrm{C}$ for $30 \mathrm{~s}$, and annealing and extension at $54^{\circ} \mathrm{C}$ for $30 \mathrm{~s}$. Melt curves were also analyzed to insure only one product per well. Primer sequences were designed using Primer3 software (http://frodo.wi.mit.edu) and ordered from Integrated DNA Technologies. Primer sequences and GenBank accession numbers for the genes selected for PCR validation are listed in Table 1. Each reaction was done in triplicate wells on one plate, and each plate was run in duplicate or triplicate. Fold change between ipsilateral and contralateral CN was calculated with the comparative $\mathrm{C}_{\mathrm{T}}$ method. Ribosomal protein L3 (RPL3) was used as the control gene.

Immunohistochemistry for Iba1 and PCNA. Mice were overdosed with sodium pentobarbital and perfused transcardially with saline followed by $4 \%$ paraformaldehyde. Brains were removed and postfixed for an additional $2 \mathrm{~h}$ at room temperature, serially dehydrated in ethanol, cleared in methyl salicylate, embedded in paraffin and cut into $10 \mu \mathrm{m}$ coronal sections. After removing paraffin, antigen retrieval was performed for Ibal in $10 \mathrm{~mm}$ citric acid, $\mathrm{pH}$ 6.0, in a steamer for $25 \mathrm{~min}$. Endogenous peroxidases were quenched in $3 \% \mathrm{H}_{2} \mathrm{O}_{2}$ for $10 \mathrm{~min}$. Tissue sections were blocked in normal serum, and incubated overnight at $4^{\circ} \mathrm{C}$ with the primary antibodies [rabbit anti-Iba1, 1:2000; Wako Chemicals USA; mouse anti-proliferating cell nuclear antigen (PCNA) 1:4000, Oncogene Cat\# NA-03-200 mg]. Tissue was rinsed and incubated in biotinylated goat anti-rabbit

(1:200) or horse anti-mouse (1:400) secondary antibody (Vector Laboratories), then in Vector avidin-biotin complex solution and reacted with diaminobenzidine (Sigma). Slides were washed, dehydrated, and coverslipped with DPX (BDH Laboratories). Sections for PCNA labeling were also lightly counterstained in $0.7 \%$ Eosin.

Analysis of tissue labeled for Iba1. Photomicrographs were taken using a CoolSnap HQ Digital Camera (Photometrics) under a $20 \times$ objective on a Zeiss Axioplan 2 microscope. Images were captured and analyzed using Slidebook4.0 software (Intelligent Imaging Innovations). CN area was calculated and a minimal intensity threshold was defined (2 SDs away from background). The total stained area above threshold was divided by total $\mathrm{CN}$ area to determine percentage of area covered by Ibal label. Three sections were chosen through the extent of AVCN in two to three mice for each age and time point ( 24 and $48 \mathrm{~h}$ ). Photomicrograph figures were prepared using Photoshop7.0 (Adobe Systems).

Analysis of tissue labeled for PCNA. Mice age P30 underwent unilateral cochlear removals and survived for $24,48,96$, or $192 \mathrm{~h}(n=2-3$ mice/ time point). Control mice at each time point did not undergo surgery and were pooled together for the final analysis $(n=4)$. Anti-PCNA stained tissue sections were viewed under a $20 \times$ objective on a Nikon E- 800 microscope. Positive cells were counted within AVCN bilaterally. A cell was defined as PCNA positive if it met the following criteria: (1) PCNA staining was darkly positive, (2) staining was nuclear, not in a blood vessel or vacuole or damaged area of tissue, (3) nuclei were small (consistent with the size of glial nuclei). Ten to 14 sections comprising the rostrocaudal extent of the $\mathrm{CN}$ were counted per mouse. The total number of PCNA positive cells counted for each animal was multiplied by 6 , because slides were analyzed from a 1 in 6 series. Means and SEs were calculated. No corrections were applied for double counting because all comparisons were made between the two sides of the same brain.

\section{Results}

\section{Gene expression profiling in the deafferented cochlear nucleus}

Microarrays were used to screen for transcriptional responses to cochlear removal at both ages during and after this critical period of afferent-dependent neuron survival. We compared the responsive genes to identify key candidates that might define the critical period and, importantly, the ability of more mature neurons to survive the same deprivation conditions. The entire microarray datasets, both raw and normalized, have been deposited in the Gene Expression Omnibus public repository (http://www.ncbi.nlm.nih.gov/geo/; series number GSE5394 and GSE11726).

Previous studies showed that deafferentation-induced neuron death in neonatal animals occurs by $96 \mathrm{~h}$ after the surgery (Mostafapour et al., 2000). Therefore, gene expression in the $\mathrm{CN}$ was assessed at four key time points after cochlear removal preceding maximal neuron loss during the critical period: 6, 12, 24, and 48 h. Identical time points were analyzed at P7 and P21. For each age and time point, relative gene expression was compared between the $\mathrm{CN}$ ipsilateral to cochlear removal with the contralateral control CN. Scatterplots of the average intensity measurements for all 22,624 gene probes on these arrays from the ipsilateral and control CN are shown in Figure $1 A$. Genes were 
A
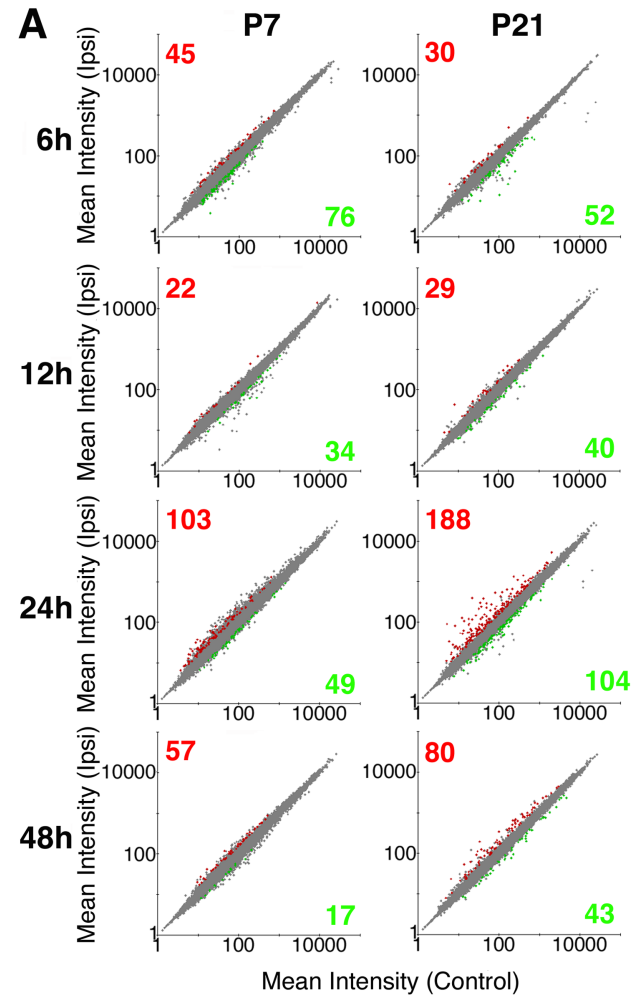

Figure 1. Number of genes regulated by cochlear removal in the $\mathrm{CN}$ during and after the critical period. $\boldsymbol{A}$, The mean log intensities in the $\mathrm{CN}$ ipsilateral to cochlear removal for all probes represented on the array are plotted against the contralateral side for P7 and P21 at 6, 12, 24, and $48 \mathrm{~h}$. Differential expression was defined as $\geq 1.5$-fold change ratio and $p$ value $\leq 0.05$ after at test. Genes meeting these criteria are shown in red (upregulation) and green (downregulation), whereas genes that did not change significantly are shown in gray. The actual number of regulated genes at each time point is shown in the corners of each graph. A similar number of genes were regulated by cochlear removal at both ages; the largest response occurred at $24 \mathrm{~h}$ for both P7 and P21. B, Venn diagrams showing the number of genes either up- or downregulated collapsed over time for P7 and P21. The overlapping areas show the number of genes that met the criteria for differential expression in both ages after cochlear removal. Only $10 \%$ of the genes were shared, whereas the majority of genes responsive to cochlear removal were different during compared with after the critical period.

identified as differentially expressed (regulated) if they met two criteria: ( 1$) \geq 1.5$-fold change up or down and (2) a $p$ value $\leq 0.05$ after a $t$ test. False discovery rate analysis using the Benjamini and Hochberg correction was then applied to this prefiltered list of genes. All genes were accepted at a FDR of 5\%. Similar numbers of genes were up- and downregulated at each time point and age, with a particularly large number of upregulated genes observed $24 \mathrm{~h}$ after surgery in both P7 and P21 CN. These gene sets, collapsed across time, were compared between P7 and P21 (Fig. 1 B). Surprisingly, although the totals for the two age groups were similar, there was remarkably little overlap in the transcriptional response to cochlear removal at P7 and P21. Only 10\% of all regulated genes appeared in both the critical period and postcritical period gene sets. Eight genes were regulated in opposite directions after cochlear removal at P7 vs P21 (data not shown).

Temporal patterns of changes in gene expression after cochlear removal in both age groups were also analyzed. Each regulated gene (identified in at least one time point as above) was assigned one of 80 possible permutations of expression over time. If a gene showed a trend toward up- or downregulation at other time points ( $>1.3$-fold change, $p \leq 0.05$ or $>1.5$-fold change, $p \geq 0.05$ ) it was included in the corresponding pattern. All temporal expression patterns representative of at least one gene in either age are shown in Figure 2. Most genes with significant expression changes were uniquely regulated at one time point only (Fig. 2A), compared with a sustained response over time (Fig. $2 B$ ) or a "switching" pattern, from up- to down-, or downto upregulated over time (Fig. 2C). However, as shown in Figure $2 B$, more genes at P21 were up- or downregulated in at least two of the time points compared with P7 (76 vs 24 upregulated, 61 vs 15 downregulated). In contrast, as shown in Figure $2 C$, many more genes at P7 switched over time from up- to downregulated or down- to upregulated. Thus, mRNA levels appear to be more dynamically regulated over time after cochlear removal in the $\mathrm{CN}$ that undergoes significant neuron loss, whereas changes in mRNA levels were more sustained after cochlear removal when all neurons ultimately survive this challenge. Correlation analyses between the fold changes measured at all time points for the groups of regulated genes gave a similar result. At $\mathrm{P} 21$, fold change ratios for individual genes were positively and significantly correlated with each other at all time points, with 24 and $48 \mathrm{~h}$ showing the highest level of correlation $(r=0.507 ; p<$ 0.01 , two-tailed $t$ test). In contrast, there were significant negative or no correlations between time points at P7, with the exception of a significant positive correlation between fold changes measured at 6 and $48 \mathrm{~h}(r=0.341, p<0.01)$. These dynamic changes at P7 most likely have a real biological basis and are not caused by random noise in the microarray data. Both P7 and P21 datasets were carefully selected based on significance criteria and showed repeatable changes across biological replicates at each time point.

\section{Biological functions of regulated genes}

All of the genes identified as significantly changed in expression after cochlear removal were assigned one of nineteen functional categories (Fig. 3). Functional classifications were based on the GeneOntology Consortium and published literature (Ashburner et al., 2000). These data were collapsed across time, because we found no evidence of any one function dominating at one time point vs another. For each function, the number of genes downregulated by cochlear removal was subtracted from the number of upregulated genes to measure the net, or preferred, direction of change. Positive values indicate that more genes were upregulated than downregulated, and vice versa for negative values. Ten of these functional groups had the same preferred direction of change after cochlear removal at P7 and P21. Eight of 10 showed net upregulation; including cell cycle, immune, proteolysis, inhibitors of proteolysis, protein synthesis, transcription, transport, and unknown categories. Cell adhesion and extracellular matrix genes were downregulated at both ages. Seven of these 19 functions had a different preferred direction of change at P7 and $\mathrm{P} 21$. Functions with more upregulated genes by cochlear removal at P21 only included apoptosis, DNA repair, heat shock or stress, and metabolism genes. The induction of more proapoptotic genes at P21 compared with P7 was surprising. At P7, ion chan- 
nels, signal transduction, and structural or cytoskeletal genes were upregulated by cochlear removal. Signal transduction contained the largest net number of upregulated genes at P7.

By far the largest effect was seen in the immune-related group of genes, with the size of the group eight times larger at P21 compared with P7. These genes are listed in Figure $4 A$, and include typical markers of microglia and macrophages, such as CD68, CD11b, and Iba1. Most of these changes occurred at the later time points examined, but a few genes changed as early as $6 \mathrm{~h}$. The relative changes in expression levels after cochlear removal for 4 genes on this list were also measured using real-time RT PCR (Fig. 4B). For the purposes of this study, we defined validation as fold changes in the same direction measured by PCR and microarray. Changes in these 4 genes after cochlear removal were confirmed for the time points considered significant by microarray analyses. In addition, there were some differences noted by PCR at time points that did not reach significance in the array analyses. For example, PCR detected an increase in Ccl12 at all time points after cochlear removal, not just 6 and $24 \mathrm{~h}$.

\section{Microglial activation following cochlear removal after the critical period}

These gene expression changes suggested the presence of an active microglial response to cochlear removal after the critical period that is absent during the critical period. To verify this, we measured the percentage of $\mathrm{CN}$ area covered with Ibal immunoreactivity, a marker of activated microglia, 24 and $48 \mathrm{~h}$ after cochlear removal at P7 and P21. As shown in Figure 4C, control mice at both ages had approximately equal levels of Ibal in the ipsilateral and contralateral $\mathrm{CN}$ (ratio $=1)$. In agreement with the microarray results for Iba1, we observed a 2.65 ( \pm 0.166 SD)fold increase in the amount of Ibal antibody label in the ipsilateral CN $48 \mathrm{~h}$ after cochlear removal at P21. This value was significantly greater than that seen at $48 \mathrm{~h}$ in $\mathrm{P} 7$ mice $(1.05 \pm 0.130$, two-tailed $t$ test: $p<0.01)$. We found no indication of an increase in Ibal protein (or mRNA) levels over controls at these time points in the P7 CN (Fig. 4C).

The upregulation of immune gene expression after cochlear removal could be caused by activation or proliferation of endogenous glia, or recruitment of macrophages from peripheral sources. We analyzed the cell cycle response in the CN over time after deafferentation in postcritical period mice. AVCN was labeled for proliferating cell nuclear antigen, PCNA, which detects cells that have exited $G_{0}$. We did not validate the use of PCNA with additional markers of cell proliferation in the current study, but PCNA expression has previously been shown to strongly correlate with the incorporation of BrdU (Valero et al., 2005). There was a significant increase in PCNA labeling in the CN ipsilateral to surgery between 24 and $48 \mathrm{~h}$ after cochlear removal compared with controls (Fig. $4 D$, two tailed $t$ test: $p<0.02$ ). Thus, endogenous glial proliferation occurring between 24 and $48 \mathrm{~h}$ after cochlear removal likely contributes to the large changes in immune gene expression seen here after the critical period.

\section{Candidate gene selection}

Single genes were identified as candidates for underlying either the death or survival response at P7 and P21 based on functions described in the literature. Twenty-seven candidate genes that could theoretically promote neuronal death, either through upregulation of death-related genes or downregulation of survivalrelated genes were selected at P7 (Fig. 5A). These critical period candidates include genes with known apoptotic functions such as caspase 12 (Momoi, 2004), and FLASH (Imai et al., 1999). The
Upregulated

$\begin{array}{llllll}6 & 12 & 24 & 48 & \text { P7 } & \text { P21 }\end{array}$

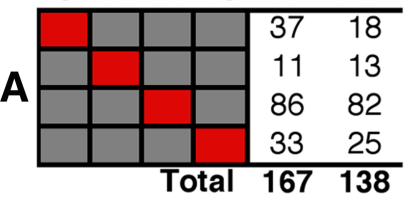

$\begin{array}{llllll}6 & 12 & 24 & 48 & \text { P7 } & \text { P21 }\end{array}$

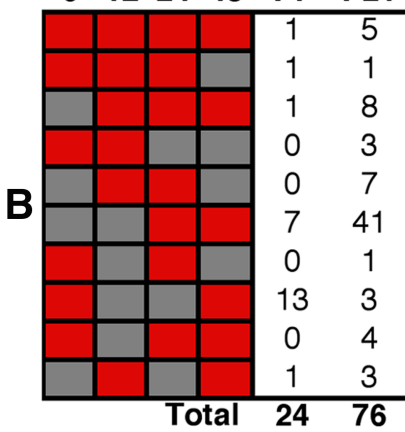

$\begin{array}{llllll}6 & 12 & 24 & 48 & \text { P7 } & \text { P21 }\end{array}$

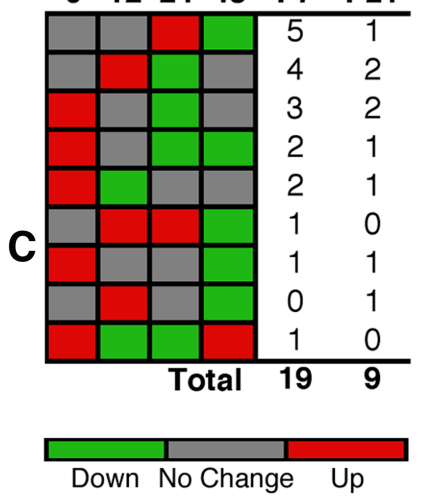

Downregulated

$\begin{array}{llllll}6 & 12 & 24 & 48 & \text { P7 } & \text { P21 }\end{array}$

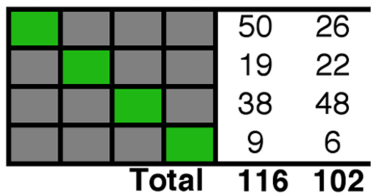

$\begin{array}{llllll}6 & 12 & 24 & 48 & \text { P7 } & \text { P21 }\end{array}$

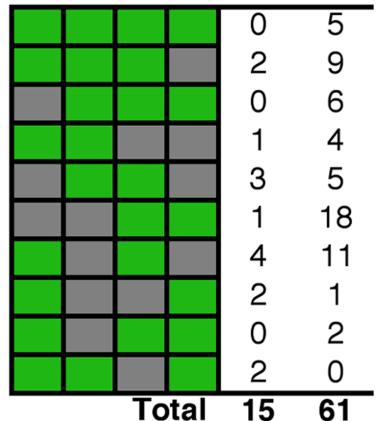

$\begin{array}{llllll}6 & 12 & 24 & 48 & \text { P7 } & \text { P21 }\end{array}$

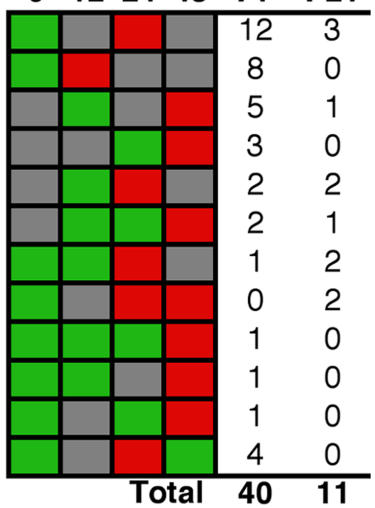

Figure 2. Temporal patterns of gene expression changes after cochlear removal during and after the critical period. There are 80 possible patterns a single gene could exhibit over time after cochlear removal. The numbers of genes at P7 and P21 exhibiting each expression pattern are shown to the right in each panel. Only those patterns with at least one gene are illustrated here. $\boldsymbol{A}$, Patterns of genes upregulated or downregulated at one time point only. $\boldsymbol{B}$, Patterns of genes with sustained upregulation or downregulation at more than one time point. C, Patterns of genes that switched in expression from up- to downregulated or down- to upregulated over time. Note that most genes showed a change in expression at one time point only $(\boldsymbol{A})$. Many more P21 genes showed a sustained response compared with P7 $(\boldsymbol{B})$, and more P7 genes exhibited a switching pattern over time (C). For each time point, red $=$ significantly up, green $=$ significantly down, gray $=$ no change.

identity of the bcl-x splice variants (either bcl-xL or bcl-xS) detected by the Affymetrix probe set is unclear because it could detect one or both isoforms. This could be determined by further PCR analyses, but we did not differentiate between possible variants in validation experiments. Bcl-xL is anti-apoptotic, whereas Bcl-xS is proapoptotic (Boise et al., 1993; Akgul et al., 2004). Other candidates include DNA repair molecules, like topoisomerase II $\beta$, where decreased expression could further sensitize the critical period neurons to DNA damage-induced death. Immature CN cells may also be made more vulnerable to oxidative stress and apoptotic death by the depletion of glutathione synthetase (Bains and Shaw, 1997). The decreased expression of parathyroid hormone-related protein (PTHrP) may be an indication of activity deprivation, and is protective in cerebellar granule neurons against excitotoxicity (Ono et al., 1997; Brines et al., 


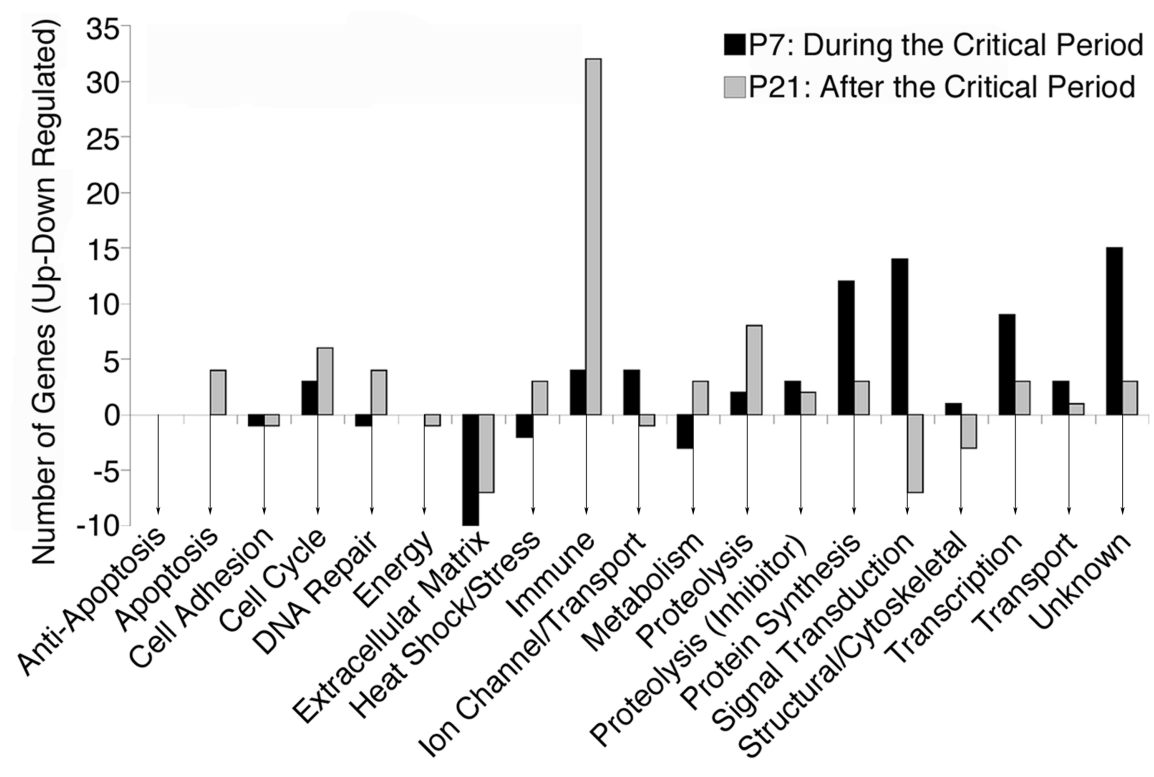

Figure 3. Distribution of functional categories after cochlear removal during and after the critical period. Up-and downregulated genes were categorized into one of 19 functional groups. To determine the net direction of change for each category the number of downregulated genes was subtracted from the number of upregulated genes both during (black) and after (gray) the critical period. Several functions showed net changes in different directions during and after the critical period. Apoptosis, cell cycle, heat shock/stress, and metabolism showed more up- than downregulated genes at P21, whereas ion transport, signal transduction, and structural/cytoskeletal genes showed more up- than downregulated genes at P7 compared with P21. The majority of genes upregulated by cochlear removal had immune-related functions at P21. At P7, signal transduction genes comprised the largest group, with the exception of unknowns. Note also that there was no net up or downregulation of the apoptotic group during the critical period at P7.

1999). We also observed a significant increase in expression of the Rho kinase Rock1, which plays an essential role in the fragmentation and phagocytosis of apoptotic cells (Orlando et al., 2006). Several candidate transcription factors were also downregulated, including CREM, a cAMP responsive transcription factor similar to CREB. A CREM splice variant, ICER, inhibits CREB/CREM mediated gene transcription and may be important in regulating neuron death (Mioduszewska et al., 2003). We focused on selecting pro-death responses at P7, but 16 genes were also identified that could potentially promote survival of these neurons (data not shown).

Although there is support for the critical period candidate genes discussed above to have a permissive role in cell death after afferent deprivation, the number of genes selected based on the literature review was relatively small during the critical period compared with after the critical period. At P21, 47 genes of 402 were selected that could theoretically promote $\mathrm{CN}$ neuronal survival, either through upregulation of survival or downregulation of death-related genes (Fig. $5 B$ ). These candidates also displayed a variety of functions, such as the induction of the anti-apoptotic $\mathrm{Bcl} 2$ family member A1 and the downregulation of Perp, a p53inducible gene that mediates p53-dependent apoptosis (Ihrie et al., 2003). Expression of multiple stress and heat shock-induced genes with neuroprotective properties increased after cochlear removal, including heme oxygenase (Panahian et al., 1999), heat shock protein 22 (Morrow et al., 2004), heat shock protein 25 (hsp25) (Benn et al., 2002), and metallothionein 1 (Giralt et al., 2002; Natale et al., 2004). Interestingly, multiple genes in Figure $5 B$ are involved in regulating the expression and function of hsp25, including c-Jun, ATF3, p38 MAPK, and Mkp1 (Benn et al., 2002; Nakagomi et al., 2003). An intriguing pair of immunerelated genes induced by cochlear removal with known neuro- protective properties were the macrophage-colony stimulating factor (Csf) and its receptor (CsfR) at 24 and $48 \mathrm{~h}$, respectively (Mitrasinovic et al., 2005). Finally, although we focused on prosurvival responses at $\mathrm{P} 21,21$ genes were identified that could potentially promote death (data not shown).

\section{Real-time RT PCR validation of selected candidate genes}

Real-time RT PCR was used as an alternate method to measure fold change ratios between the deafferented and contralateral cochlear nuclei for 42 genes selected predominantly from Figure 5, but also from the general lists of regulated genes. Scatterplots in Figure $6 \mathrm{~A}$ show the relationship between PCR and array measurements for all genes at the time point(s) they were considered significantly regulated by microarray analyses, as well as the time points that did not reach significance. For both P7 and P21, there was a statistically significant positive correlation between PCR and microarray results for the genes identified as significantly regulated by array analysis $(r=0.613$ at $\mathrm{P} 7$ and $r=0.725$ at P21; $p<0.01$, two-tailed $t$ test). There were weak (P21) or no (P7) correlations between PCR and microarray results for genes that did not pass the microarray selection criteria, as shown in the open circles of Figure $6 \mathrm{~A}$. Previous studies have observed a similar low concordance between these measures for genes with low fold changes, even finding cases in which fold change appears in opposite directions (Morey et al., 2006). Eleven of 23 genes at P7, and 18 of 19 genes at P21 were validated by real-time RT PCR. Bar plots in Figure 6, $B$ and $C$, show validation of the direction and magnitude of fold changes measured for six genes at P7 (Fig. $6 B$ ) and P21 (Fig. 6C), including the Hsp25 related genes mentioned above. Fold change ratios were measured at each of the four time points, not just the time point(s) considered significant for each gene. Note the good agreement between the microarray and PCR results in both direction and magnitude of fold change ratios at the time point considered significant using microarrays (asterisks). Some differences were observed in the magnitude, but not the direction of change for a few genes, e.g., HO1 and Hsp25. Most of the other "nonsignificant" time points showed a PCR fold change $<1.5$, also in agreement with the microarray results. There were a few exceptions, including a sustained increase in calpain 5 expression from 12 to $48 \mathrm{~h}$, and more dynamic changes in KLF4 expression at 24 and $48 \mathrm{~h}$ using PCR. Overall, fold changes measured by PCR and microarray were highly and significantly correlated, especially when genes were first filtered for significance in the microarray data (Fig. 6A).

\section{Activity-dependent changes in gene expression}

The changes in gene expression after surgical removal of the cochlea could be predominantly caused by elimination of electrical activity at the eighth nerve- $\mathrm{CN}$ synapses. Alternatively, a factor that is not controlled by action potential-mediated signaling could be differentially released from the eighth nerve under normal or damaged conditions and could elicit the transcriptional 
A

\begin{tabular}{|c|c|c|c|c|c|}
\hline \multicolumn{6}{|c|}{ Immune-Related Genes Regulated by Cochlear Removal at P21 } \\
\hline 6 & 12 & 24 & 48 & Gene Name & Accession \# \\
\hline & & & & Chemokine (C-X-C motif) ligand 12 & NM_013655 \\
\hline & & & & CD276 & NM_133983 \\
\hline & & & & Inducible T-cell co-stimulator & NM_017480 \\
\hline & & & & IL 2 receptor, gamma chain & L20048 \\
\hline & & & & Chemokine (C-C motif) ligand 12 & U50712 \\
\hline & & & & Oncostatin $\mathrm{M}$ receptor & NM_011019 \\
\hline & & & & CD36 & BE307351 \\
\hline & & & & Chemokine (C-C motif) ligand 3 & NM_011337 \\
\hline & & & & CD68 & ВC021637 \\
\hline & & & & C-type lectin domain family $7 \mathrm{a}$ & NM_020008 \\
\hline & & & & Thymidylate kinase homologue & AK004595 \\
\hline & & & & CD83 & NM_009856 \\
\hline & & & & Pentraxin related gene & NM_008987 \\
\hline & & & & CD44 & ВC005676 \\
\hline & & & & Leukocyte Ig-like receptor B4 & U05264 \\
\hline & & & & Complement component $3 \mathrm{a}$ receptor & ВС003728 \\
\hline & & & & CD14 & NM_009841 \\
\hline & & & & Complement component 3 & K02782 \\
\hline & & & & Lymphocyte antigen 86 & NM_010745 \\
\hline & & & & Interleukin 13 receptor, alpha 1 & BI081033 \\
\hline & & & & Macrophage scavenger receptor 2 & ВС016551 \\
\hline & & & & Fc receptor, IgG, low affinity Iib & BM224327 \\
\hline & & & & Fc receptor, $\operatorname{IgE}$, high affinity I & NM_010185 \\
\hline & & & & CD53 & NM_007651 \\
\hline & & & & Small inducible cytokine A10 & NM_011338 \\
\hline & & & & CD52 & NM_013706 \\
\hline & & & & IL 1 receptor accessory protein & NM_008364 \\
\hline & & & & CD84 & NM_013489 \\
\hline & & & & Colony stimulating factor 1 & BM233698 \\
\hline & & & & C1q (gamma) & NM_007574 \\
\hline & & & & C1q (beta) & BB111335 \\
\hline & & & & Interleukin 11 & NM_008350 \\
\hline & & & & C1q (alpha) & NM_007572 \\
\hline & & & & Fc gamma receptor III & NM_010188 \\
\hline & & & & TREM2 & NM_031254 \\
\hline & & & & Allograft inflammatory factor 1 (Iba1) & NM_019467 \\
\hline & & & & Alpha-2-macroglobulin & BB185854 \\
\hline & & & & Colony stimulating factor 1 receptor & AI323359 \\
\hline & & & & CD11b & NM_008401 \\
\hline & & & & Cyclooxygenase 1 & AA833146 \\
\hline
\end{tabular}

B
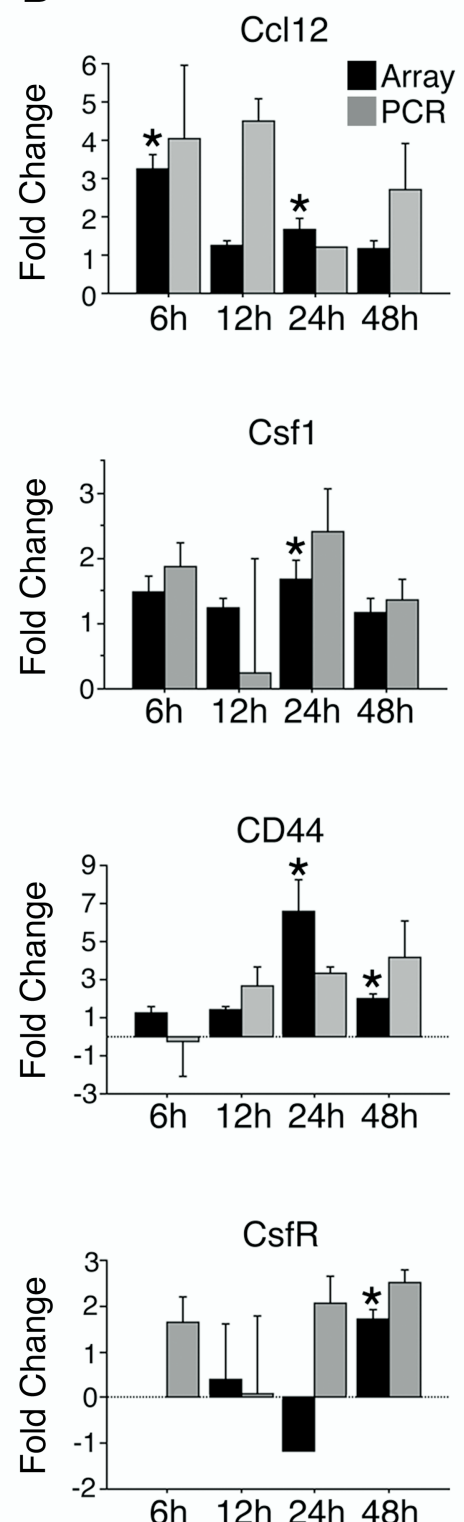

C
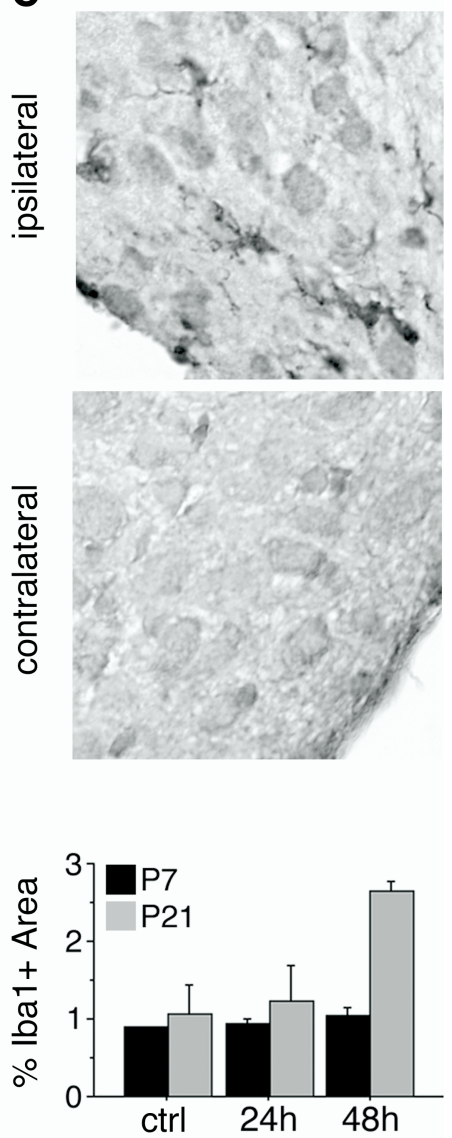

D

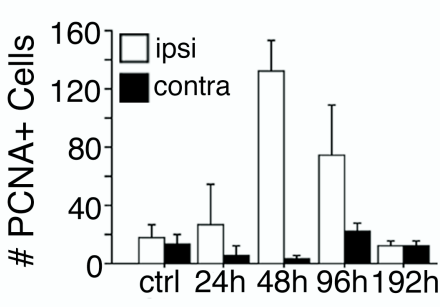

Down No Change Up

Figure 4. Regulation of immune genes and glial cells after the critical period. $A$, All genes significantly up- and downregulated by cochlear removal with immune roles at P21 are listed by time of appearance. $B$, Confirmation of microarray results for 4 of these immune-related genes. Fold change ratios measured using microarrays (black) and real-time RT PCR (gray) are shown at 6, 12, 24, and $48 \mathrm{~h}$ after cochlear removal. The asterisk indicates the time points at which the microarray results were considered significant. All 4 of these genes showed a change using PCR in the same direction and of similar magnitude as the significant time points for the microarray results. Error bars indicate 1SD. C, Immunohistochemical analysis of microglial Iba1 immunoreactivity 24 and $48 \mathrm{~h}$ after cochlear removal at P7 and P21. Representative examples of Iba1 labeling after $48 \mathrm{~h}$ of afferent deprivation in the P21 CN ipsilateral and contralateral to surgery. The percentage of total CN area covered with Iba1 + cells was significantly greater in the ipsilateral CN $48 \mathrm{~h}$ after surgery at P21, but not when surgery was done during the critical period at P7. Scale bar, $50 \mu \mathrm{m}$. D, The number of cells that have left $\mathrm{G}_{0}$ as indicated by PCNA immunolabeling was quantified over time after cochlear removal in the postcritical period CN. Proliferation peaked at $48 \mathrm{~h}$ and returned to control levels by $192 \mathrm{~h}$ after cochlear removal in the ipsilateral CN. Error bars indicate SEM.

changes observed here in the $\mathrm{CN}$. To begin to separate these causes, we performed two different analyses. First, we electrically silenced the eighth nerve unilaterally in both P7 and P21 mice with tetrodotoxin (TTX) for $6 \mathrm{~h}$ and analyzed a subset of cochlear removal-regulated genes by real-time RT PCR. Second, we blocked eighth nerve activity with TTX in P21 mice for $24 \mathrm{~h}$ using an osmotic pump, and screened for activity-dependent changes in $\mathrm{CN}$ gene expression using microarrays. For both experiments, relative gene expression was compared between the $\mathrm{CN}$ ipsilateral to TTX with the contralateral unmanipulated CN. We were limited to older mice for the longer-term TTX exposure experiment because of the size of young postnatal mice relative to the smallest osmotic pumps. TTX does not cause any overt damage to cochlear structure (data not shown, but see Pasic and Rubel, 1989; Sie and Rubel, 1992). Mice are completely deafened by TTX exposure in the eighth nerve as measured by auditory brainstem responses (ABR), and this blockade is fully reversible (Fig. 7C) (Pasic and Rubel, 1989). As an additional control for TTX effectiveness, c-Fos expression was analyzed after $6 \mathrm{~h}$ by real-time RT PCR at both ages. c-Fos levels were decreased in both P7 and P21 $\mathrm{CN}$ (Fig. 7). Although c-Fos was not downregulated at any time by cochlear removal on the P7 microarrays, it was consistently observed $6 \mathrm{~h}$ after cochlear removal using PCR.

For the first set of experiments using both P7 and P21 mice, we 
A

\begin{tabular}{|c|c|c|c|c|c|}
\hline \multicolumn{6}{|c|}{ Candidate Genes Regulated by CR during the Critical Period } \\
\hline 6 & 12 & 24 & & Gene Name & Accession \# \\
\hline \multicolumn{6}{|c|}{ Apoptosis } \\
\hline \multirow[t]{5}{*}{$\mathbf{V}$} & & & & $3 \mathrm{cl}-\mathrm{X}$ & U10100 \\
\hline & & & & $3 \mathrm{cl}-10$ & AF100339 \\
\hline & & & & DNA fragmentation factor, alpha & BB446076 \\
\hline & & & & Caspase 12 & NM_009808 \\
\hline & & & & LASH & NM_011997 \\
\hline \multicolumn{6}{|c|}{ Cell Cycle } \\
\hline & & & & Cyclin B1 & NM_007629 \\
\hline \multicolumn{6}{|c|}{ DNA repair / replication } \\
\hline & & & & Topoisomerase II beta & BB166592 \\
\hline & & & & Checkpoint kinase 1 & NM_007691 \\
\hline \multicolumn{6}{|c|}{ Extracellular Matrix } \\
\hline & & & & Osteopontin & NM_009263 \\
\hline \multicolumn{6}{|c|}{ Metabolism } \\
\hline & & $\mathbf{V}$ & & Glutathione synthet & NM_008180 \\
\hline & & & & rostaglandin D2 synthase & $A B 006361$ \\
\hline & & & & phingosine phosphate lyase 1 & BC026135 \\
\hline \multicolumn{6}{|c|}{ Proteolysis } \\
\hline & & $\mathbf{V}$ & & Calpain 5 & BC014767 \\
\hline \multicolumn{6}{|c|}{ Signal Transduction } \\
\hline & & & & arathyroid hormone-related protein & BI685341 \\
\hline & & & & Tachykinin 1 & NM_009311 \\
\hline & & & & NF k B inhibitor, alpha & AI462015 \\
\hline & & & & Rock1 & BB667679 \\
\hline & & & & I3K (p85 alpha) & M60651 \\
\hline \multicolumn{6}{|c|}{ Structural / Cytoskeletal } \\
\hline & & & & Keratin complex 2 , basic, gene 8 & NM_031170 \\
\hline & & & & & \\
\hline \multicolumn{6}{|c|}{ Transcription / Chromatin } \\
\hline & & & & $\operatorname{marcd} 2$ & BM230202 \\
\hline $\mathbf{V}$ & & & & CAMP responsive element modulator & AI467599 \\
\hline \multirow[t]{5}{*}{$\mathbf{V}$} & & & & Kruppel-like factor 4 & U20344 \\
\hline & & & & Kruppel-like factor 2 & NM_008452 \\
\hline & & & & Early growth response 1 & NM_007913 \\
\hline & & & & tat 2 & AF088862 \\
\hline & & & & tat1 & NM_009283 \\
\hline
\end{tabular}

B

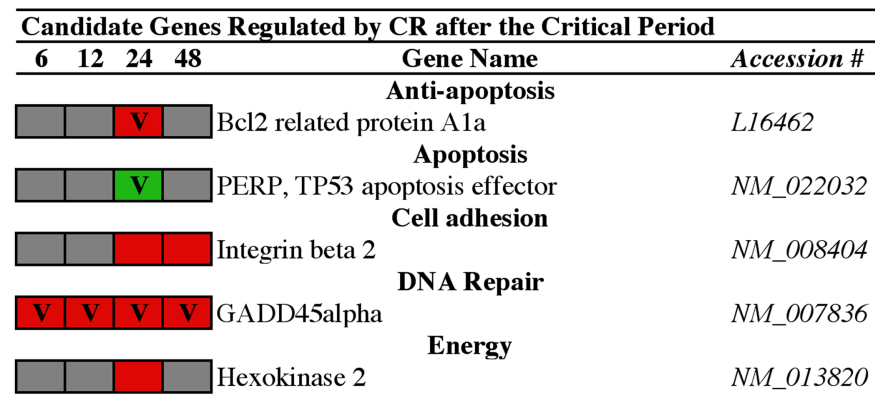

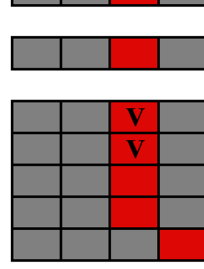

Extracellular Matrix

Heat Shock / Stress

BC008107

NM_010442

U03561

BC027262

NM_030704

NM_009264

NM_011019

NM_008987

BI081033

BM233698

NM_008350

AI323359

Metabolism

Colony stimulating factor 1 receptor

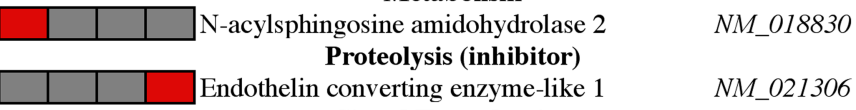

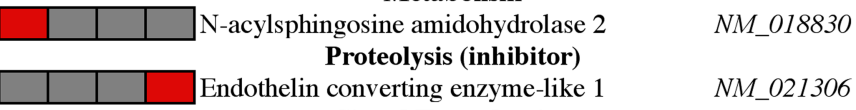

NM_013642

BC018397

NM_009153

NM_008154

NM_013749

BC004650

AV024285

NM 009311

U28216

NM_008151

NM_008915

$B B 241535$

NM_010101

NM_010415

$\begin{array}{ll}\text { Heparin-binding EGF-like growth factor } & \text { NM_O10415 } \\ \text { Cardiotrophin-like cytokine factor 1 } & B B 825816 \\ \text { Rab6 interacting protein } 2 & B C 002272\end{array}$

$\begin{array}{ll}\text { Heparin-binding EGF-like growth factor } & \text { NM_O10415 } \\ \text { Cardiotrophin-like cytokine factor 1 } & B B 825816 \\ \text { Rab6 interacting protein } 2 & B C 002272\end{array}$

Cell adhesion molecule, homology to L1CAM NM_007697

Igf binding protein $2 \quad$ AKO11784

p38 delta MAPK NM_011950

PTP, non-receptor type $6 \quad$ NM_013545

Rho GDI beta AK002516

\begin{tabular}{|l|l|l|l|ll}
\hline \multicolumn{3}{|c|}{ Transcription / Chromatin } \\
\hline & $\mathbf{V}$ & $\mathbf{V}$ & $\mathbf{V}$ & Nur77 & NM_010444 \\
\hline & $\mathbf{V}$ & $\mathbf{V}$ & $\mathbf{V}$ & Jun oncogene & BCOO2081 \\
\hline & & & & Activating transcription factor 3 & BCO19946 \\
\hline & & & & Bc13 & NM_033601 \\
\hline & & & & MEF2A & AV255689 \\
\hline & & & & Stat3 & AI325183 \\
\hline & & & & Stat5b & AKO04083
\end{tabular}

Figure 5. Selected candidate genes. $A$, Genes with possible roles in promoting cell death that were regulated after cochlear removal during the critical period in the P7 CN. B, Genes with possible roles in promoting cell survival that were regulated by cochlear removal after the critical period in the P21 CN. Differential expression was defined by $\geq 1.5$-fold change and a $p$ value $\leq 0.05$. Genes are arranged by broad functional categories. The "V" marks genes also validated by real-time RT PCR.

chose a subset of genes regulated $6 \mathrm{~h}$ after cochlear removal that were also validated with real-time RT PCR. At P7, 3 of 7 genes were downregulated after TTX to a similar degree seen after cochlear removal (Fig. 7D). These genes were c-Fos, caspase 3, and the transcription factor Kruppel like factor 4 (KLF4). Sham surgery did not result in any changes in gene expression (fold change
$<1.5$ ). Three other genes analyzed at P7 (Bcl-x, ICAD, and lumican) did not significantly change in expression after TTX (data not shown). At P21, 5 of 6 genes downregulated $6 \mathrm{~h}$ after cochlear removal surgery were also downregulated by TTX (Fig. 7E). These genes included known activity-dependent genes, such as c-Fos, BDNF, and Nur77, but also included two genes not previ- 
ously well described as activity-dependent; the MAPK dual specificity phosphatase 1 gene (Mkp-1) and a p53 induced mediator of cell death, Perp. One gene analyzed at P21 did not change in expression after TTX; an immune-related gene upregulated by cochlear removal (Ccl12).

We thought a more extensive comparison between activity-deprivation and deafferentation in this system would provide a clearer answer to the identity of the signal eliciting transcriptional changes. So we used microarrays to profile gene expression in the CN $24 \mathrm{~h}$ after implantation of an osmotic pump delivering TTX into the cochlea of P21 mice. As shown in Figure $8 A$, TTX delivered in this way completely eliminated the ABR for at least $24 \mathrm{~h}$ after surgery. Utilizing the same selection criteria as for the cochlear removal microarrays, we identified a surprisingly small number of genes significantly regulated by activity deprivation (Fig. $8 B, C$ ). Therefore, for further analyses we relaxed the selection criteria to include genes showing trends toward up- or downregulation as described previously for the time course analyses. Activity deprivation elicited expression changes in 176 genes, 37 of these were also regulated after cochlear removal at one of the four time points. This accounted for $10.6-24.6 \%$ of deafferentation-induced transcriptional changes at each time point. The total list of genes regulated by both deafferentation and cochlear removal is shown in Figure $8 D$. Many known activity-dependent genes were identified, again including c-Fos, BDNF, and Nur77. Interestingly, a large proportion of these genes showed a pattern of sustained regulation across time after cochlear removal (based on trends), suggesting a diagnostic tool for identifying genes likely to be regulated by activity vs another factor resulting from cochlear removal. Several candidates previously identified in Figures 4 and 5 were also regulated by activity deprivation. Of particular interest was the upregulation of the immune-related genes CSF-1 and CD83, suggesting that alterations in action potential-mediated signaling in the eighth nerve can regulate expression of these predominantly microglial/macrophage gene products, although the mechanisms by which this might occur is unknown.

\section{Discussion}

Mechanisms defining developmental critical periods of enhanced synaptic plasticity and age-dependent susceptibilities to manipulations of afferent activity are not clearly understood, although progress has been made in the visual system (for review, see Hensch, 2005). In the auditory system, afferent input is required for the survival of cochlear nucleus neurons during a critical period of postnatal


Figure 6. Validation of microarray results using-real time RT PCR. $\boldsymbol{A}$, The relationship between PCR and microarray measurements of fold change ratios for a subset of genes at the time point(s) they were considered significantly regulated by microarray analyses. There was a significant positive correlation between $P C R$ and microarray results for both ages $(p<0.01)$. $\boldsymbol{B}, \boldsymbol{C}$, Twelve examples of genes identified by microarray analysis at P7 $(\boldsymbol{B})$ and $P 21(\boldsymbol{C})$ validated by PCR. The fold change ratios measured using microarrays (black) and real-time RT PCR (gray) are shown at 6, 12,24, and $48 \mathrm{~h}$ after cochlear removal for each gene. The asterisk indicates the time point at which the microarray results were considered significant. Error bars indicate 1 SD.

development (for review, see Harris et al., 2006). The molecular basis of this period of neuronal vulnerability is not known. In an earlier study we identified candidate genes with differences in constitutive mRNA expression that could underlie the increased susceptibility of immature $\mathrm{CN}$ neurons to deafferentation by 
A
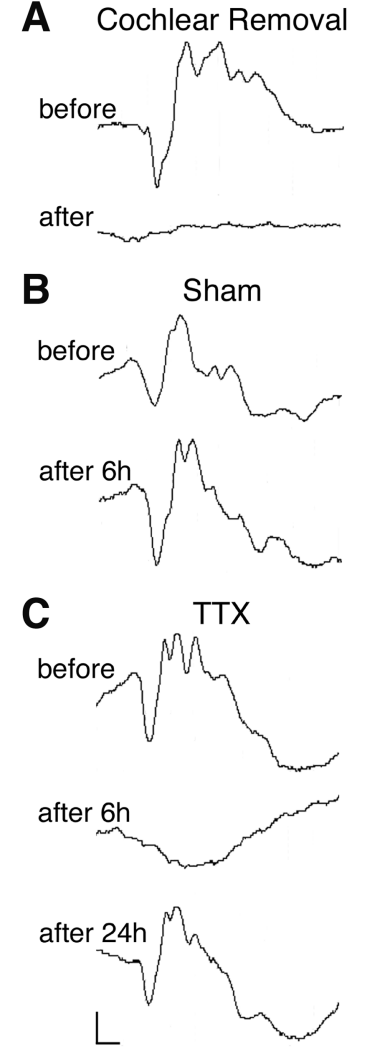

within the first $48 \mathrm{~h}$ (unpublished electron microscopy observations, E. Rubel and L. Westrum). Therefore, the immune response is most likely a result of the deafferentation, and loss or gain of one or more factors released from the eighth nerve terminals damaged at a distal site. At both ages, one of the earliest gene expression changes was the upregulation of Ccl12, a macrophage chemoattractant signal (Sarafi et al., 1997). Ccl12 mRNA expression remained elevated through $48 \mathrm{~h}$ at P21, but returned to control levels by the same time at P7. This early induction of a macrophage chemoattractant at P21 was followed by evidence of a macrophage or microglial presence, including increased expression of CD68, CD14, CD11b, $\mathrm{m}$-CSF1, and Ibal genes. The source of these microglia/macrophages is currently unknown, but could include newly proliferated cells from endogenous precursors. Our PCNA labeling would support this hypothesis, but the contribution of peripheral macrophages or microglia from outside the $\mathrm{CN}$ during and after the critical period should also be investigated. Previous data also suggested appropriate glial activation could contribute to $\mathrm{CN}$ neuron survival after the critical period (Zhao and Lurie, 2004).

A key developmental event defining the end of this critical period could be glial maturation enabling cells to respond quickly and helpfully to a challenge. Recently, astrocytes were shown to mediate synapse elimination in retinal ganglion cells by inducing classical complement cascades in neurons during a critical period of development (Stevens et al., 2007).

comparing baseline gene expression at ages during compared with after this critical period (Harris et al., 2005). Here we used microarrays to show that the transcriptional response to cochlear removal is also very different in $\mathrm{CN}$ tissue in which neurons are able to survive versus die after deafferentation. There was surprisingly little overlap in genes regulated by cochlear removal in the entire CN at P7 compared with P21, although these numbers could have been underestimated by not sampling specific cell types in the $\mathrm{CN}$ tissue. We further verified microarray estimates of fold change for a subset of these genes with real-time RT PCR, and demonstrated an increase in reactive microglia and cell proliferation that could be the source of the large immune response detected at P21. Finally, we found that although activity deprivation contributes to the transcriptional regulation of genes identified after cochlear removal, it is not likely to be the sole signal.

The most striking result was the induction of a very large group of immune-related genes in the more mature $\mathrm{CN}$. Although this response might be initially interpreted as direct damage to the $\mathrm{CN}$ tissue after surgical removal of the cochlea, this is highly unlikely for several reasons. We do not observe any evidence of damage to the $\mathrm{CN}$ after cochlear aspiration (no broken bone or blood spilled into the brain), and indeed degeneration of eighth nerve axon terminals in the $\mathrm{CN}$ is not even apparent
Notably, the time when retinogeniculate synaptic connections are refined corresponds with the occurrence of immature astrocytes. In adult visual cortex of cats, transplantation of immature astrocytes reinstated ocular dominance plasticity, supporting the proposal that mature astrocytes limit plasticity (Müller and Best, 1989). It is intriguing to propose a related model in the $\mathrm{CN}$ based on our data in which mature glial cells promote stability of the neurons and their network connections.

Other neuronally expressed immune-related genes have been implicated in activity-dependent refinement of synaptic connections during critical periods of visual system development (Huh et al., 2000). For example, the MHC-I receptor PirB restricts neuronal plasticity in the visual cortex (Syken et al., 2006). We also identified a PirB family member, leukocyte immunoglobulin-like receptor B4, induced by afferent deprivation after the critical period (Fig. $4 A$ ). Classically defined immune genes, regardless of the cell type in which they are expressed, may function broadly in the mature nervous system to promote stability or refinement of synaptic connections and neuron number.

One clear result from these profiling studies was that deafferentation elicits an active transcriptional response after the critical period. We were surprised to observe more genes with proapoptotic functions induced by afferent deprivation in the P21 CN, 
including caspases 1,3 , and 12, as well as the bcl-2 family member, Bim. New transcription of Bim is necessary for trophic factor withdrawal-induced neuronal apoptosis (Putcha et al., 2001), and is induced by activity deprivation in cerebellar granule neurons undergoing apoptosis (Shi et al., 2005). These results strongly indicate that the P21 CN is actively responding to this manipulation as if it were an apoptotic challenge, even though the neurons ultimately survive. Deafferentation did not elicit a large apoptotic transcriptional response in the P7 CN, despite the fact that many neurons die an apoptotic-like death. In fact, there were only 2 clear-cut examples of genes that could promote death during the critical period: FLASH and caspase 12. Of course, baseline levels of proapoptotic gene expression are constitutively higher in the P7 CN (Harris et al., 2005), and CN neurons activate caspases as part of the cell death process (Mostafapour et al., 2000), so perhaps new transcription of these apoptotic genes is not necessary for cell death during the critical period.

Many effects of cochlear removal in the $\mathrm{CN}$ can be completely accounted for by blocking action-potential mediated activity in the auditory nerve; including neuron loss in chickens, and cell shrinkage and decreased protein synthesis in chickens and gerbils (Born and Rubel, 1988; Pasic and Rubel, 1989; Sie and Rubel, 1992). Because synaptic activation controls neuronal gene expression through several possible pathways (West et al., 2002), we predicted that changes in gene expression after cochlear removal were caused by the lack of action potential-mediated signaling from eighth nerve terminals. Unlike previously assayed metabolic changes, the microarray and PCR analyses conducted here indicated that activity deprivation does not completely account for cochlear removalinduced gene expression changes at either P7 or P21. It should be noted that we could have underestimated the extent to which activity-deprivation and cochlear removal overlap because of technical differences in the magnitude and duration of the pharmacological blockade. Regardless, factors in addition to action potential-mediated signaling are very likely involved in regulation of gene transcription after cochlear removal. These could either be factors released into the $\mathrm{CN}$ after injury to the cochlea, or a factor that is blocked from release or transport down the axon by the injury to the cochlea. The identity of these signals will require further exploration.

Gene expression profiling is emerging as an important tool for generating hypotheses that encompass and recognize the multicomponent nature of plasticity or stability in the nervous system (Harris et al., 2005; Majdan and Shatz, 2006; Tropea et al., 2006).
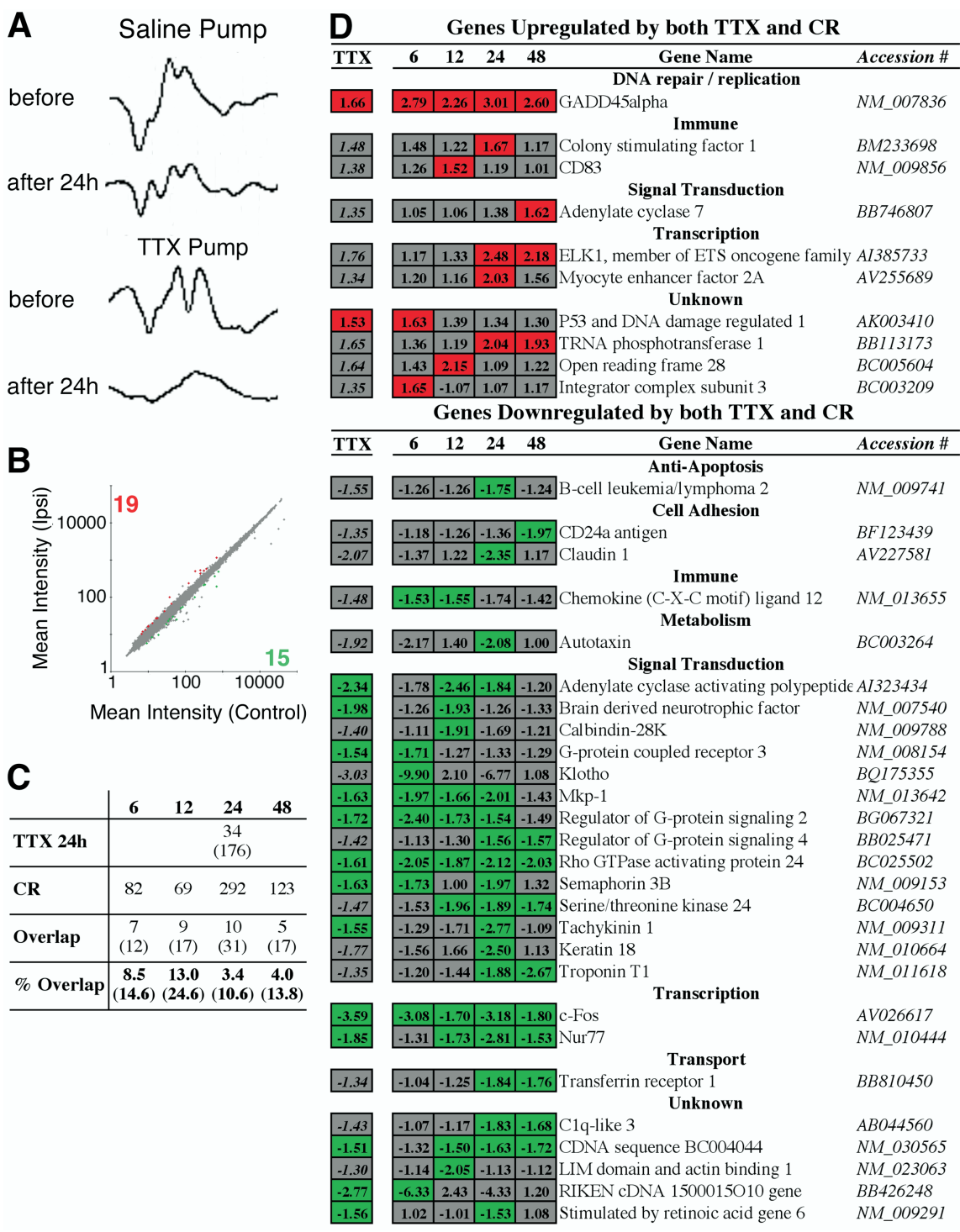

Figure 8. Effects of TTX delivered by osmotic pump on hearing and gene expression. $\boldsymbol{A}$, Auditory brainstem responses are shown as in Figure 7. 0smotic pumps filled with saline do not deafen mice as measured by ABR $24 \mathrm{~h}$ later. TTX does eliminate the ABR for up to $24 \mathrm{~h}$ after osmotic pump implantation. $\boldsymbol{B}$, The mean log intensities in the P21 CN after $24 \mathrm{~h}$ of TTX for all probes represented on the array are plotted against the contralateral, control side. Differential expression was defined as $\geq 1.5$-fold change ratio and $p$ value $\leq 0.05$ after a $t$ test. Genes meeting these criteria are shown in red (upregulation) and green (downregulation), whereas genes that did not change significantly are shown in gray. $\boldsymbol{C}$, Listed are the number of genes identified by microarray analyses after $24 \mathrm{~h}$ of TTX or cochlear removal (CR) at 6, 12,24, and $48 \mathrm{~h}$. The first numbers are significant by the criteria listed above. The numbers in parentheses refer to genes that have met relaxed selection criteria ( $F C>1.3$ with $p \leq 0.05$ or $F C$ $>1.5$ with $p \geq 0.05$ ). Even with the relaxed selection criteria, only $10-25 \%$ of the genes regulated by cochlear removal at any time point are also regulated by $24 \mathrm{~h}$ of TTX exposure. $\boldsymbol{D}$, All genes up- and downregulated by both TTX and cochlear removal are listed by broad functional categories. Genes that met the more strict selection criteria are shown in red or green, with the fold change values listed in all boxes. Genes regulated by both TTX and cochlear removal included several already on the P21 candidate list, and previously verified by real-time RT PCR.

We previously proposed a model in which constitutive gene expression in the immature $\mathrm{CN}$ favors a default death response to afferent deprivation, and maturation changes this to a default survival program after the critical period (Harris et al., 2005). We determined that caspase 3, caspase 7, BID, Bok, and p75 expression were all at significantly higher baseline levels during the period of susceptibility to afferent deprivation. We can now extend this model to suggest that the core apoptotic machinery during the critical period is already in place, so transcriptional regulation of these genes is not necessary for cell death after deaf- 
ferentation. Similar conclusions were drawn from a microarray study of cerebellar granule neurons undergoing $\mathrm{KCl}$ deprivationinduced apoptosis in vitro (Desagher et al., 2005). After the end of the critical period, the death/survival balance under baseline conditions seems tipped in favor of survival. A possible mechanism could be that auditory neurons after the critical period experience higher rates of synaptic activity, both evoked and spontaneous, because of the onset of hearing (Lu et al., 2007). Bouts of synaptic activity can have long-lasting protective effects on neurons through CREB-mediated transcription of prosurvival gene expression (Soriano et al., 2006). Although afferent deprivation elicited an apoptotic transcriptional response in the more mature $\mathrm{CN}$, there was further induction of neuroprotective genes, still favoring survival in the overall balance. The mature nervous system appears to have many active mechanisms in place, likely in multiple cell types, to prevent inappropriate neuron loss and promote stability of network connections. Further studies of how these mechanisms develop could help us understand both the enhanced plasticity of the immature nervous system and the failure of these survival mechanisms in age-related neurodegenerative diseases.

\section{References}

Akgul C, Moulding DA, Edwards SW (2004) Alternative splicing of Bcl-2related genes: functional consequences and potential therapeutic applications. Cell Mol Life Sci 61:2189-2199.

Ashburner M, Ball CA, Blake JA, Botstein D, Butler H, Cherry JM, Davis AP, Dolinski K, Dwight SS, Eppig JT, Harris MA, Hill DP, Issel-Tarver L, Kasarskis A, Lewis S, Matese JC, Richardson JE, Ringwald M, Rubin GM, Sherlock G (2000) Gene ontology: tool for the unification of biology. The Gene Ontology Consortium. Nat Genet 25:25-29.

Bains JS, Shaw CA (1997) Neurodegenerative disorders in humans: the role of glutathione in oxidative stress-mediated neuronal death. Brain Res Brain Res Rev 25:335-358.

Benn SC, Perrelet D, Kato AC, Scholz J, Decosterd I, Mannion RJ, Bakowska JC, Woolf CJ (2002) Hsp27 upregulation and phosphorylation is required for injured sensory and motor neuron survival. Neuron 36:45-56.

Boise LH, González-Garcia M, Postema CE, Ding L, Lindsten T, Turka LA, Mao X, Nuñez G, Thompson CB (1993) bcl-x, a bcl-2-related gene that functions as a dominant regulator of apoptotic cell death. Cell 74:597-608.

Born DE, Rubel EW (1985) Afferent influences on brain stem auditory nuclei of the chicken: neuron number and size following cochlea removal. J Comp Neurol 231:435-445.

Born DE, Rubel EW (1988) Afferent influences on brain stem auditory nuclei of the chicken: presynaptic action potentials regulate protein synthesis in nucleus magnocellularis neurons. J Neurosci 8:901-919.

Brines ML, Ling Z, Broadus AE (1999) Parathyroid hormone-related protein protects against kainic acid excitotoxicity in rat cerebellar granule cells by regulating L-type channel calcium flux. Neurosci Lett 274:13-16.

Brunjes PC (1994) Unilateral naris closure and olfactory system development. Brain Res Brain Res Rev 19:146-160.

Desagher S, Severac D, Lipkin A, Bernis C, Ritchie W, Le Digarcher A, Journot L (2005) Genes regulated in neurons undergoing transcriptiondependent apoptosis belong to signaling pathways rather than the apoptotic machinery. J Biol Chem 280:5693-5702.

Giralt M, Penkowa M, Lago N, Molinero A, Hidalgo J (2002) Metallothionein- $1+2$ protect the CNS after a focal brain injury. Exp Neurol 173:114-128.

Harris JA, Rubel EW (2006) Afferent regulation of neuron number in the cochlear nucleus: Cellular and molecular analyses of a critical period. Hear Res 216-217:127-137.

Harris JA, Hardie NA, Bermingham-McDonogh O, Rubel EW (2005) Gene expression differences over a critical period of afferent-dependent neuron survival in the mouse auditory brainstem. J Comp Neurol 493:460-474.

Hashisaki GT, Rubel EW (1989) Effects of unilateral cochlea removal on anteroventral cochlear nucleus neurons in developing gerbils. J Comp Neurol 283:5-73.
Hensch TK (2005) Critical period plasticity in local cortical circuits. Nat Rev Neurosci 6:877-888.

Huh GS, Boulanger LM, Du H, Riquelme PA, Brotz TM, Shatz CJ (2000) Functional requirement for class I MHC in CNS development and plasticity. Science 290:2155-2159.

Ihrie RA, Reczek E, Horner JS, Khachatrian L, Sage J, Jacks T, Attardi LD (2003) Perp is a mediator of p53-dependent apoptosis in diverse cell types. Curr Biol 13:1985-1990.

Imai Y, Kimura T, Murakami A, Yajima N, Sakamaki K, Yonehara S (1999) The CED-4-homologous protein FLASH is involved in Fas-mediated activation of caspase-8 during apoptosis. Nature 398:777-785.

Irizarry RA, Hobbs B, Collin F, Beazer-Barclay YD, Antonellis KJ, Scherf U, Speed TP (2003) Exploration, normalization, and summaries of high density oligonucleotide array probe level data. Biostatistics 4:249-264.

Levi-Montalcini R (1949) Development of the acousticovestibular centers in the chick embryo in the absence of the afferent root fibers and of descending fiber tracks. J Comp Neurol 91:209-241.

Lu Y, Harris JA, Rubel EW (2007) Development of spontaneous miniature EPSCs in mouse AVCN neurons during a critical period of afferentdependent neuron survival. J Neurophysiol 97:635-646.

Luoma JI, Zirpel L (2008) Deafferentation-induced activation of NFAT (nuclear factor of activated T-cells) in cochlear nucleus neurons during a developmental critical period: a role for NFATc4-dependent apoptosis in the CNS. J Neurosci 28:3159-3169.

Majdan M, Shatz CJ (2006) Effects of visual experience on activitydependent gene regulation in cortex. Nat Neurosci 9:650-659.

Mioduszewska B, Jaworski J, Kaczmarek L (2003) Inducible cAMP early repressor (ICER) in the nervous system-a transcriptional regulator of neuronal plasticity and programmed cell death. J Neurochem 87:1313-1320.

Mitrasinovic OM, Grattan A, Robinson CC, Lapustea NB, Poon C, Ryan H, Phong C, Murphy GM Jr (2005) Microglia overexpressing the macrophage colony-stimulating factor receptor are neuroprotective in a microglial-hippocampal organotypic coculture system. J Neurosci 25:4442-4451.

Momoi T (2004) Caspases involved in ER stress-mediated cell death. J Chem Neuroanat 28:101-105.

Moore DR (1990) Auditory brainstem of the ferret: early cessation of developmental sensitivity of neurons in the cochlear nucleus to removal of the cochlea. J Comp Neurol 302:810-823.

Morey JS, Ryan JC, Van Dolah FM (2006) Microarray validation: factors influencing correlation between oligonucleotide microarrays and realtime PCR. Biol Proced Online 8:175-193.

Morrow G, Samson M, Michaud S, Tanguay RM (2004) Overexpression of the small mitochondrial Hsp22 extends Drosophila life span and increases resistance to oxidative stress. FASEB J 18:598-599.

Mostafapour SP, Cochran SL, Del Puerto NM, Rubel EW (2000) Patterns of cell death in mouse anteroventral cochlear nucleus neurons after unilateral cochlea removal. J Comp Neurol 426:561-571.

Mostafapour SP, Del Puerto NM, Rubel EW (2002) bcl-2 Overexpression eliminates deprivation-induced cell death of brainstem auditory neurons. J Neurosci 22:4670-4674.

Müller CM, Best J (1989) Ocular dominance plasticity in adult cat visual cortex after transplantation of cultured astrocytes. Nature 342:427-430.

Nakagomi S, Suzuki Y, Namikawa K, Kiryu-Seo S, Kiyama H (2003) Expression of the activating transcription factor 3 prevents c-Jun N-terminal kinase-induced neuronal death by promoting heat shock protein $27 \mathrm{ex}-$ pression and Akt activation. J Neurosci 23:5187-5196.

Natale JE, Knight JB, Cheng Y, Rome JE, Gallo V (2004) Metallothionein I and II mitigate age-dependent secondary brain injury. J Neurosci Res 78:303-314.

Ono T, Inokuchi K, Ogura A, Ikawa Y, Kudo Y, Kawashima S (1997) Activity-dependent expression of parathyroid hormone-related protein (PTHrP) in rat cerebellar granule neurons. Requirement of PTHrP for the activity-dependent survival of granule neurons. J Biol Chem 272:14404-14411.

Orlando KA, Stone NL, Pittman RN (2006) Rho kinase regulates fragmentation and phagocytosis of apoptotic cells. Exp Cell Res 312:5-15.

Panahian N, Yoshiura M, Maines MD (1999) Overexpression of heme oxygenase-1 is neuroprotective in a model of permanent middle cerebral artery occlusion in transgenic mice. J Neurochem 72:1187-1203.

Pasic TR, Rubel EW (1989) Rapid changes in cochlear nucleus cell size fol- 
lowing blockade of auditory nerve electrical activity in gerbils. J Comp Neurol 283:474-480.

Putcha GV, Moulder KL, Golden JP, Bouillet P, Adams JA, Strasser A, Johnson EM (2001) Induction of BIM, a proapoptotic BH3-only BCL-2 family member, is critical for neuronal apoptosis. Neuron 29:615-628.

Sarafi MN, Garcia-Zepeda EA, MacLean JA, Charo IF, Luster AD (1997) Murine monocyte chemoattractant protein (MCP)-5: a novel CC chemokine that is a structural and functional homologue of human MCP-1. J Exp Med 185:99-109.

Shi L, Gong S, Yuan Z, Ma C, Liu Y, Wang C, Li W, Pi R, Huang S, Chen R, Han Y, Mao Z, Li M (2005) Activity deprivation-dependent induction of the proapoptotic BH3-only protein Bim is independent of JNK/c-Jun activation during apoptosis in cerebellar granule neurons. Neurosci Lett 375:7-12.

Sie KC, Rubel EW (1992) Rapid changes in protein synthesis and cell size in the cochlear nucleus following eighth nerve activity blockade or cochlea ablation. J Comp Neurol 320:501-508.

Soriano FX, Papadia S, Hofmann F, Hardingham NR, Bading H, Hardingham GE (2006) Preconditioning doses of NMDA promote neuroprotection by enhancing neuronal excitability. J Neurosci 26:4509-4518.

Stevens B, Allen NJ, Vazquez LE, Howell GR, Christopherson KS, Nouri N, Micheva KD, Mehalow AK, Huberman AD, Stafford B, Sher A, Litke AM,
Lambris JD, Smith SJ, John SW, Barres BA（2007） The classical complement cascade mediates CNS synapse elimination. Cell 131:1164-1178.

Syken J, Grandpre T, Kanold PO, Shatz CJ (2006) PirB restricts oculardominance plasticity in visual cortex. Science 313:1795-1800.

Tierney TS, Russell FA, Moore DR (1997) Susceptibility of developing cochlear nucleus neurons to deafferentation-induced death abruptly ends just before the onset of hearing. J Comp Neurol 378:295-306.

Tropea D, Kreiman G, Lyckman A, Mukherjee S, Yu H, Horng S, Sur M (2006) Gene expression changes and molecular pathways mediating activity-dependent plasticity in visual cortex. Nat Neurosci 9:660-668.

Valero J, Weruaga E, Murias AR, Recio JS, Alonso JR (2005) Proliferation markers in the adult rodent brain: bromodeoxyuridine and proliferating cell nuclear antigen. Brain Res Brain Res Protoc 15:127-134.

Van der Loos H, Woolsey TA (1973) Somatosensory cortex: structural alterations following early injury to sense organs. Science 179:395-398.

West AE, Griffith EC, Greenberg ME (2002) Regulation of transcription factors by neuronal activity. Nat Rev Neurosci 3:921-931.

Wiesel TN, Hubel DH (1963) Single-cell reponses in striate cortex of kittens deprived of vision in one eye. J Neurophysiol 26:1003-1017.

Zhao J, Lurie DI (2004) Cochlear ablation in mice lacking SHP-1 results in an extended period of cell death of anteroventral cochlear nucleus neurons. Hear Res 189:63-75. 